NBER WORKING PAPER SERIES

\title{
MOVIES, MARGINS AND MARKETING: \\ ENCOURAGING THE ADOPTION OF IRON-FORTIFIED SALT
}

\author{
Abhijit Banerjee \\ Sharon Barnhardt \\ Esther Duflo \\ Working Paper 21616 \\ http://www.nber.org/papers/w21616 \\ NATIONAL BUREAU OF ECONOMIC RESEARCH \\ 1050 Massachusetts Avenue \\ Cambridge, MA 02138 \\ October 2015
}

For financial support, we thank the International Initiative for Impact Evaluation, the U.K. Department for International Development, the U.S. National Institutes of Health (P01AG005842), and the International Food Policy Research Institute. Dr. Vandana Shiva provided medical expertise. For dedicated research support we are grateful to the team at J-PAL, including Urmi Bhattacharya, Shruti Bhimsaria, Anna George, Dwijo Goswami, Radhika Jain, Seema Kacker, Sweta Kumari, Bastien Michel, Prianthi Roy, Krutika Ravishankar, Achill Rudolph, Laura Stilwell, Niloufer Taber, Micah Villareal and dozens of survey specialists. We thank Amitabh Chandra and participants at the Health and Aging conference at the Boulders, 2015 for comments. All errors are our own. The views expressed herein are those of the authors and do not necessarily reflect the views of the National Bureau of Economic Research.

At least one co-author has disclosed a financial relationship of potential relevance for this research. Further information is available online at http://www.nber.org/papers/w21616.ack

NBER working papers are circulated for discussion and comment purposes. They have not been peerreviewed or been subject to the review by the NBER Board of Directors that accompanies official NBER publications.

(C) 2015 by Abhijit Banerjee, Sharon Barnhardt, and Esther Duflo. All rights reserved. Short sections of text, not to exceed two paragraphs, may be quoted without explicit permission provided that full credit, including $\odot$ notice, is given to the source. 
Movies, Margins and Marketing: Encouraging the Adoption of Iron-Fortified Salt Abhijit Banerjee, Sharon Barnhardt, and Esther Duflo

NBER Working Paper No. 21616

October 2015

JEL No. I12,I15

\begin{abstract}
A set of randomized experiments shed light on how markets and information influence household decisions to adopt nutritional innovations. Of 400 Indian villages, we randomly assigned half to an intervention where all shopkeepers were offered the option to sell a new salt, fortified with both iron and iodine (and not just iodine) at 50\% discount. Within treatment villages, we conducted additional interventions: an increase in retailer margin (for one or several shopkeepers), the screening of an "edutainment" movie on the benefits of double-fortified salt, a flyer informing households of the product's availability, and free distribution to a subset of households. We find that two interventions - showing the short film and offering an incentive to all shopkeepers - significantly increased usage: both by 5.5 percentage points, or over $50 \%$, over take up without intervention, three years after launch. For comparison, only about half of households given the salt for free actually consumed it.
\end{abstract}

Abhijit Banerjee

Department of Economics, E17-201A

MIT

77 Massachusetts Avenue

Cambridge, MA 02139

and NBER

banerjee@mit.edu

Sharon Barnhardt

Indian Institute of Management - Ahmedabad

Vastrapur

Ahmedabad 380015

INDIA

barnhardt@iimahd.ernet.in
Esther Duflo

Department of Economics, E17-201B

MIT

77 Massachusetts Avenue

Cambridge, MA 02139

and NBER

eduflo@mit.edu 


\title{
Movies, Margins and Marketing:
}

\section{Encouraging the Adoption of Iron-Fortified Salt}

\author{
Abhijit Banerjee, Sharon Barnhardt, and Esther Duflo*
}

\begin{abstract}
A set of randomized experiments shed light on how markets and information influence household decisions to adopt nutritional innovations. Of 400 Indian villages, we randomly assigned half to an intervention where all shopkeepers were offered the option to sell a new salt, fortified with both iron and iodine (and not just iodine) at $50 \%$ discount. Within treatment villages, we conducted additional interventions: an increase in retailer margin (for one or several shopkeepers), the screening of an "edutainment" movie on the benefits of double-fortified salt, a flyer informing households of the product's availability, and free distribution to a subset of households. We find that two interventions - showing the short film and offering an incentive to all shopkeepers - significantly increased usage: both by 5.5 percentage points, or over $50 \%$, over take up without intervention, three years after launch. For comparison, only about half of households given the salt for free actually consumed it.
\end{abstract}

\section{Introduction}

Anemia is estimated to affect 1.6 billion people worldwide (de Benoist et al., 2008). Iron deficiency is one of the leading causes of anemia, along with other nutritional deficiencies, illness and disease (diarrhea and malaria), and infections (parasites) (Viteri, 1998). anemia, (IDA) is associated with slower physical and cognitive development (Lozoff, 2007), with potentially long-lasting effects (Lozoff et al. 2006). For working-age adults, productivity may be lowered by IDA, as feeling weak is the most common symptom of the disorder (Haas and Brownlie, 2001). Severe

\footnotetext{
*Banerjee and Duflo are from the Massachusetts Institute of Technology and Barnhardt is from the Indian Institute of Management - Ahmedabad. For financial support, we thank the International Initiative for Impact Evaluation, the U.K. Department for International Development, the U.S. National Institutes of Health (P01AG005842), and the International Food Policy Research Institute. Dr. Vandana Shiva provided medical expertise. For dedicated research support we are grateful to the team at J-PAL, including Urmi Bhattacharya, Shruti Bhimsaria, Anna George, Dwijo Goswami, Radhika Jain, Seema Kacker, Sweta Kumari, Bastien Michel, Prianthi Roy, Krutika Ravishankar, Achill Rudolph, Laura Stilwell, Niloufer Taber, Micah Villareal and dozens of survey specialists. We thank Amitabh Chandra and participants at the Health and Aging conference at the Boulders, 2015 for comments. All errors are our own.
} 
anemia during pregnancy can lead to low birth weight and child mortality (Stoltzfus, 2001). High rates of anemia are observed broadly among older adults. Lower hemoglobin levels in the elderly are associated with cognitive decline (Peters et al., 2008) and lower physical performance (Penninx et al., 2004).

Fortified foods are a potential solution for widespread iron-deficiency anemia.1 Model-based estimates suggest that, compared to iron supplementation, iron fortification is less expensive and would be more cost effective at a large scale for reducing maternal and neonatal mortality (Baltussen et al. 2004). For iron fortification to be effective, the fortified food must be something households routinely consume. Grains like wheat were seen as promising in north India, but only for the relatively richer households who buy flour. For poorer households who consume their own grains, fortification at small mills requires behavioral changes by households that seem to be unsustainable (Banerjee et al., 2011).

Salt seems to be an ideal product to fortify: it is ubiquitous, cheap, and generally purchased from stores. Consumers have brand loyalty and prefer white branded salt over the grayish traditional rock salt. Adding iron to branded salts thus seems to be a promising way to increase iron intake and reduce IDA. In the mid 1990s, its promise, DFS was not commercially available until recently, due to technical difficulties in insuring the stability of both the iron and the iodine. In the mid 2000s, India's National Institute of Nutrition (NIN, Hyderabad) developed double-fortified salt (DFS), fortified with iron and iodine. DFS is estimated to provide about $30 \%$ of the RDA of iron (National Institute of Nutrition (India), 2005) when consuming 10g salt per day regularly (fortified at $1 \mathrm{mg}$ iron/g salt) (Ranganathan and Sesikeran, 2008). NIN scientists first demonstrated the long-term safety of DFS in animal studies (Nair et al., 1998). They also established the stability and bioavailability of iron in DFS and the acceptability and effectiveness of DFS in school children and small-scale trials with tribal populations Nair et al. 1998; Brahmam et al., 2000; Sivakumar et al., 2001).

In the last five years, NIN and the Indian Govenrment have sought to encourage wider adoption of DFS. Since 2011, the NIN formulation of DFS can be manufactured by private companies through a license agreement requiring a certain percentage of production to be donated

$1 \quad$ Bhutta et al. (2013) describe the full list of nutritional interventions aimed at women and children as "education, dietary modification, food provision, agricultural interventions, supplementation and fortification...alone and in combination, provision of financial incentives...home gardening and community-based nutrition education and mobilization programs." 
to charities such as school meal programs. In 2012, India's Department of Women and Child Welfare directed states to use DFS in the national mid-day meal scheme (school lunches) and the Integrated Child Development Scheme (Mudur, 2013). Several manufacturers produce and market DFS, including Tata Chemicals Limited. Tata is one of the leading manufacturers of salt in India, and we used their DFS, branded as "Tata Salt Plus" for our study. The maximum retail price of Tata Salt Plus is 20 rupees (₹20) per kg, making it a relatively low-cost iron source, but around twice the price of regular iodized salt $:^{2}$

Suprisingly, the nationwide scale-up of DFS in school meals and the approval for retail, has happened despite the lack of large-scale efficacy trials of DFS: we only have a few effectiveness studies, all among women and children in carefully monitored environments (Mudur, 2013).

This paper is part of a larger project to fill this gap and assess the potential impact of a nationwide subsidy on double-fortified salt. There are three overarching questions to answer: (1) What would be the demand for double fortified salt, even if it were subsidized, and at what price would demand be sustained over time? (2) Could that demand be increased through marketing approaches? (3) What is the population-wide impact of DFS?

We examined the first question in a previous paper Banerjee et al. (2013) with a small scale, individual-level, randomized pricing experiment to determine the demand curve for DFS. We found that demand falls sharply at a price of ₹10 per kilogram, the price of the cheapest alternative branded salt. Just under a third of the households seem willing to try it just below that price. To answer question (3) we set up two experiments. First, a free distribution experiment which will help us determine the causal impact of salt consumption and, more broadly, whether demand multiplied by impact would be sufficient to make a difference in population health, cognitive and physical capacities, and productivity, and second, a large scale impact evaluation, where in 200 villages (randomly chosen out of 400), all shopkeepers were given the opportunity to stock Tata Salt plus, at a special research MRP of 9 rupees, and we measured health and productivity outcome at baseline and approximately three years after the introduction of the product.

This paper focuses on question (2). $\mathrm{w}=$ We analyze a set of experiments, conducted in the 200 villages where tata salt plus was made availabile, in order to understand whether different forms of social marketing can boost demand for double-fortified salt. Within these villages, we

$2 \quad$ Tata Salt, which is the highest quality iodine fortified salt available, normally sells for ₹ 15 per kg. 
conducted the following experiments. First, we commissioned a high production value 26-minute edutainment movie, and screened it during an intermission midway through a free showing of a very popular film. Modeled on a sitcom and starring prominent actors from local language cinema, the movie was widely seen, and was entertaining as well as informative. This is in keeping with the effort of companies like MTV to convey health messages through entertaining TV shows, but contrasts with the more dour style of the traditional public health documentary. Second, we sought to incentivize shopkeepers by randomly providing either one or all of them in a given village with higher margins to sell the product (Ashraf et al., 2012). In a lighter touch experiment, we also distributed hand-delivered flyers in some villages in the sample households: the idea was to make sure that households in the sample knew of the existence of the product. Finally, we distributed DFS to some households at not charge in order to measure the impact on actual consumption and downstream biological and economic impacts of having the salt at home for free. In this paper, we use the results of free distribution on take-up as a benchmark for the effect of the other interventions.

\section{Context and Data}

\subsection{Anemia in Bihar}

Bihar is a large and poor state in north India, with nearly one-third of its 103 million residents living under the poverty line as of 2012 (Planning Commission and others, 2013). According to the National Family Health Survey, $67 \%$ of adult women, $34 \%$ of adult men, and $78 \%$ of children under the age of three years suffered from some form of anemia in 2005-06 (International Institute for Population Sciences (IIPS) and Macro International, 2008). Wendt et al. (2015) found that only $37 \%$ of pregnant women in Bihar received the recommended iron supplement in 2007-2008 and only $24 \%$ of them consumed the supplement for 90 days.

We worked across all 14 administrative blocks of Bhojpur District (which has a population of 2.7 million). In the State Health Society's January 2014 ranking of districts in terms of medical service provision, Bhojpur came it at number 17 out of 38 (Statehealthsocietybihar.org, 2015). For the study, we randomly selected 28 or 29 villages in each block to get a total of 400 villages. Our "main" experiment is the marketing of double-fortified salt to shopkeepers in randomly assigned treatment villages compared to the remaining main control villages where DFS is not 
offered. We randomly assigned $50 \%$ of the villages in each block to be treatment and $50 \%$ to be control, ending up with 200 of each for the main experiment.

Our data come from detailed household surveys at baseline and endline. The timing of endline data collection was approximately two years after DFS was introduced 3 Purchase data come from a household salt purchase module, answered by the household head (male or female) who had the most knowledge about household purchases and assets. The baseline also includes modules on household composition, consumption and expenditure, use of health services, time use, cognition, and physical health. Baseline data is described in some detailed in Banerjee et al. (2013).

\subsection{Baseline Data and Attrition}

Table 1 shows some baseline descriptive statistics of the sample 4 and balance checks across treatment conditions. The households in the sample are poor but not exceptionally so by Indian standards. In the control group, $14.8 \%$ of individuals were anemic at baseline. The average household size is eight persons. Eighteen percent of the households have elderly members, an important target group for this study, given the absence of any evidence on the impact of DFS for them. Overall, the randomization seems to have produced very balanced experimental groups. The households that receive the free-DFS intervention are somewhat less likely to have older members and an educated head.

Table 2 shows that, $8 \%$ of households were lost to attrition in the 200 treatment villages, and there are no differences across samples. This paper will focus on household-level variable (purchase), and here the attrition level is fairly low; therefore, we opted not to correct for attrition with bounds or other methods. At the individual level, attrition is higher - in total, $20 \%$ of individuals surveyed at baseline were lost to follow-up. Table 3 shows that attritors were more likely to be men, less likely to be children, and less likely to be anemic. Most characteristics of the attritors are balanced across group, with one exception: attritors tend to be poorer in the "basic" experiment villages (those receiving the $50 \%$ discount alone) and in the store-incentives villages (column 7) but not in the movie experiment villages.

3 See Appendix 1 for a timeline of all activities.

4 Banerjee et al. 2013) has a much more detailed description of the baseline sample. 


\section{$3 \quad$ Experiments and Assignments}

In each main treatment village, a team of vendors approached every shop in the village, including both private kirana (grocery) stores and Public Distribution System (PDS or "fair price") shops. The team pitched the product, took orders, delivered salt to the shops, and accepted payment from the shopkeepers. Shops were then instructed to sell DFS at the special research price of ₹ 9 per $\mathrm{kg}$, discounted from the retail price of ₹20 per kg. The price was prominently displayed on the packet:5 The first time the village was visited for stocking, a marketing team from Tata Chemicals launched the product. To highlight the importance of a diet sufficiently rich in iron, team members played games with children in the village that required endurance, gave away T-shirts and hats to the winners, and explained the key benefits of consuming DFS. After approaching all shops in all 200 villages this way, a new round of stocking began. In all, we completed 12 rounds of stocking between August 2012 and May 2015. Tata stocked 446,732 kilograms of DFS, 160,958 in the PDS shops and 285,774 in private kiranas.

Within each village, we randomly selected 15 households from the District Rural Development Authority household listing to form the measurement sample. All of the experiments reported in this paper take place within the 200 main experiment villages and measure the impact on the nearly 3000 measurement households living in them ${ }^{6}$

Our earlier work in the district (Banerjee et al. 2013$)$ suggested shopkeepers may have an important influence on which salt consumers choose. Our field team observed several shoppers ask generally for a package of salt and shopkeepers give a package without asking which brand or type the consumer wanted. This is confirmed in the reasons given to buy salt in the data we collected for this study: in the main experiment group with no other intervention, $41 \%$ of households who bought DFS did so because this is what the shopkeeper gave them, and $8 \%$ because it is what he recommended. The shopkeeper's incentive to choose DFS over other salts or to exert more effort marketing DFS may be important in the adoption of DFS. On the other hand, previous research (Ashraf et al., 2012) raises the possibility that for a low-demand product

$\overline{5} \quad$ At this price level, Banerjee et al. (2013) established an initial take-up of approximately $30 \%$ in Behea Block of Bhojpur district.

$6 \quad$ In 62 randomly selected main treatment villages, we randomly assigned seven households to receive free DFS from May 2013 until the endline survey back-checking was completed. This was to measure the impact on health (not take-up, which is the focus of this paper). We therefore control for both Free DFS Village and Free DFS Household in all of our regressions. 
that represents only a small part of the retail business, financial incentives may have no impact. In that study, financial incentives for selling female condoms were given to hairdressers. The setting here is different, however: the product is less exotic and may be easier to convince households to try. In particular, households do regularly buy salt, and the shopkeeper just needs to get them to buy this particular type. In contrast, in Ashraf et al. (2012), the average control group hairdressers only sold seven packs of two condoms over the course of a year.

Since the impact of retailer incentives is an empirical question, we conducted an experiment to determine the impact of increasing the private shopkeeper's margin on household adoption. This experiment happened during the fifth round of stocking (August-December 2013) in the 189 main treatment villages that had at least two kiranas. Shopkeepers selected for the treatment group got an additional discount of ₹3 per $\mathrm{kg}$ on the wholesale price of DFS, without any requirement to decrease the price charged to the final consumer 7 It was then the shopkeeper's choice to reduce the price, increase marketing, or do something else. We randomized these villages into three equal groups, those in which: one shop gets the discount, all shops get the discount, and no shop gets the discount (control). This design was chosen to enable the study of how shopkeeper behavior (including price charged to customer and other marketing habits) depends on competition. Kumar et al. (2001) suggest that the pass-through may be limited when consumers lack information and only a few retailers are offered the promotion. In the 63 villages where only one shop was given the discount, we randomly selected it from all shops in the village.

Notwithstanding the influence of shopkeepers, households are the eventual decision-makers. An important challenge for the launch of a new product is making sure households know about it. Tata's launch in the village addressed this need systematically across all sales villages. However, many of the villagers probably missed the launch event, and others may not have been persuaded by it: as discussed in (Banerjee et al., 2013), our pilot experiment showed that various versions of the "standard" marketing package performed by Tata did not seem to increase the adoption rate. To address this issue, we commissioned the production of a 26 -minute movie about the health benefits of adequate iron consumption and the availability of iron in DFS. The film was meant to be entertaining, modeled on sitcoms and starring Bhojpuri actors (Bhojpuri is the local dialect of Hindi and has its own cinema industry). It tells the story of Bhim and his pregnant wife.

\footnotetext{
The normal retailer margin was roughly ₹ 1.3 per $\mathrm{kg}$.
} 
Bhim is physically small and not very strong and wants to ensure that his son (he assumes he will have a son) will grow to be a strong man. A village nurse convinces his wife of the importance of taking iron for anemia as a way of making sure that the child is healthy and strong, and after initial misgivings Bhim is convinced as well.

Earlier research has shown that edutainment movies can be effective, but there are few randomized trials on the subject. Using a difference-in-difference strategy based on the gradual introduction of cable television, Jensen and Oster (2009) and La Ferrara et al. (2012) show sizeable effects of television on behavior. In India, the introduction of cable television is associated with improvements in women's status, including increases in reported autonomy and female school enrollment and decreases in the acceptability of beating. In the case of Brazil, exposure to Rede Globo soaps featuring very small families was found to decrease fertility by an amount equivalent to the mother having two extra years of education.

Some studies focus, like us, on soap opera explicitly produced with education in mind. Rogers et al. (1999) and Rogers and Vaughan (2000) found that the radio soap opera Twende $N a$ Wakati in Tanzania had strong behavioral effects on family planning. Exposure was non-random, however, and the survey just compares exposed to unexposed households. Using mixed methods and before-after designs, Usdin et al. (2005) and Solórzano et al. (2008) find encouraging effects on risky sexual behavior and gender-based violence indicators of two popular campaigns, "Soul City" in South Africa and Puntos de Encuentro in Nicaragua. Paluck and Green (2009) and Gunhild and Zia (2013), both randomized evaluations of soap operas, found positive impacts on conflict resolution and intergroup tolerance in Rwanda and on financial literacy outcomes in South Africa, respectively. Finally, Kearney and Levine (2014) estimate that the MTV reality series "16 and Pregnant" led to a 5.7 percent reduction in teen births across the United States, which is about one-third of the overall decline in the period they studied.

To maximize viewership, we showed the movie as an intermission between two halves of the classic film Nadiya Ke Par. We showed the film and our movie twice in each movie treatment village between October and December 2013. One screening was outdoors in the evening and intended for the entire village. The second showing was intended for women and kids, and we scheduled it the next day, inside a school, daycare, medical office or somewhere else women would feel comfortable. To estimate movie viewership, we sent observers to 25 randomly selected villages, who was tasked with counting the number of men and women present. We estimate 
that a total of slightly over 50,000 people saw the movie in total (about three quarters of those in the general screening sessions, and one quarter in the sessions for women and children), which we estimate was about $15 \%$ of everyone in the village (including children). We conservatively estimate (based on some auxiliary assumptions) that this means at least one adult male saw the movie in $20 \%$ of households and at least one adult female saw it in $9.3 \%$ of households.

We conducted the movie experiment in both main treatment and main control villages, so that we could separately study the impact of the film's DFS promotion on adoption of the product where it was available in stores and the impact of the anemia prevention information in villages where DFS was not sold. The movie experiment was stratified by block, village status in the main experiment, as well as in the free DFS experiment we simultaneously conducted. In total, we randomly assigned 64 out of the 200 main treatment villages to receive the movie screenings. This paper focuses on the take-up of the fortified salt, so we focus on the part of the movie experiment that happened in the main treatment villages (since the salt was not available in the control villages).

To serve as benchmark for those interventions, we also conducted a much lighter touch information experiment. We designed a flyer that simply informed a household about DFS and where it could be bought locally. We then delivered the flyer directly to our sample households in October and November 2013. The advantage of direct marketing is that the flyer has a greater chance of reaching those women who do not go outside the home very much, but who may have different preferences for investing in health or over brands of salt. Another reason for distributing the flyer was that, in the original marketing experiment, the reduction in prices was announced through vouchers distributed at home. The flyers would allow us to say something about the part of the impact of the vouchers that came from raised product awareness, rather than the price cut. The flyer experiment was stratified by the retail incentive, movie, and free DFS experimental status. In all, we assigned 150 villages (in the main treatment group) to receive flyers. All 15 measured (sample) households were supposed to get the flyers.

Finally, in 62 villages, 7 of the 15 study households were provided with free double-fortified salt. The prime objective was to serve as a large-scale efficacy trial of the impact of doublefortified salt in the field, but this also provides a useful benchmark for the impact of the marketing experiment. The willingness to use the salt when received for free should be an upper bound for any potential impact of marketing intervention. 


\section{Results}

We estimate the impact of the different treatments using the main treatment sample of 200 villages. Given the multiple randomizations occurring across the same set of villages, we estimate all results in a single specification as follows:

$$
U_{S E} E_{h v}=\alpha+\beta_{1} * \text { Movie }_{v}+\beta_{2} * \text { Flyer }_{v}+\beta_{3} * \text { All Store }_{v}+\beta_{4} * \text { OneStore }_{v}+\beta_{5} \text { Free }_{h}+X \gamma+e_{h v}
$$

where X represents the controls: village randomized into free DFS treatment group, village not in retail incentive experiment (has $<2$ kiranas), and fixed effects at the block level. Thus, each treatment coefficient can be interpreted as the impact of this particular modification compared to a situation where this modification is not present. We work with several versions of the USE variable: currently use, ever used, current and past use, number of times purchased (or received) DFS in the last year.

Results are presented in Table 4. Without any additional intervention, just under $10 \%$ of households are currently using DFS (about two to three years after introduction of the product in their villages), and $20 \%$ have ever tried. When DFS is distributed for free, $54.6 \%$ of households do use it $(9.8 \%+44.8 \%)$, so this probably represents an upper bound of what any kind of marketing could achieve. The difference between DFS and other preventive health products such as bednets (see Dupas (2009)) is that, even at zero price, not everybody is willing to use the product. While essentially all households accepted delivery of the salt, about half of them did something else with it. Anecdotal evidence suggests that they either gave it away, re-sold it, or fed it to cows.

Against this backdrop, the movie experiment has a large impact: it increases current take-up at endline, which took place between 7 and 16 months the movie was shown, by 5.5 percentage points $(57 \%)$ and "ever used" by 11.5 percentage points $(22 \%)$. This is a much longer-term impact of a single exposure than what is typically evaluated. In most studies, the impact is measured while the movie is still being shown. We calculate that someone has seen the movie in $20 \%$ of households on average, so the impact per viewer is large. Of course, it could be that viewers share the information with others, so there is no implied instrumental variable estimate here. But it suggests that the movie was effective in convincing people to adopt double-fortified salt, and to stick with it over several rounds of purchases. The effect appears to be similar for households 
who receive free DFS and those who do not (the interaction of DFS and movie is noisy, positive for current use and negative for past use), and for those who are in the shopkeeper experiment and those who are not. It suggests that the movie shifted the demand for the salt up, regardless of the price point: it basically changed the "willingness to accept" the product rather than the willingness to pay.

In contrast with the results of Ashraf et al. (2012), increasing retailer margin also leads to an increase in sustained adoption of double-fortified salt: the point estimate for "currently using DFS" is 5.5 percentage points, almost exactly identical to the impact of the movie. Interestingly, this is only true when all the retailers were offered the incentives. The point estimate impact of the one-shop treatment is either zero or negative.

Contrary to the movie - which led both to an increase in one-time purchases (trying out the product) and persistence - the store incentive has a larger marginal impact on the fraction of households who persist with using the salt: the point estimate is smaller and insignificant for "ever purchased."

These results contrast with those for the flyer distribution, which only notified households at home of where in their village fortified salt was on sale. That treatment had absolutely no impact on purchases. This suggests that both the movie and the margin treatment affected purchase because they truly changed the way households thought about the salt, as opposed to merely reminding them of its availability.

Our next set of results is presented in Table 5. In that table, we run the following specification:

$$
\begin{array}{r}
\text { CHAR } R_{h v}=\alpha+\beta_{1} * \text { Movie }_{v} * U S E_{h v}+\beta_{2} * \text { Flyer }_{v} * U S E_{h v}+\beta_{3} * \text { AllStores }_{v} * U S E_{h v}+ \\
\beta_{4} * \text { OneStore }_{v} * U S E_{h v}+\beta_{5} \text { Free }_{h} * U S E_{h v}+\beta_{6} U S E_{h v}+X \gamma+e_{h v}
\end{array}
$$

where $C H A R_{h v}$ is a particular household characteristic, measured at baseline (e.g. number of household members), and the vector of control variable including main effects for each treatment group. Few characteristics of households who take up DFS are systematically different, compared to non-users. The only differences are that they have slightly more female members and the head is more likely to be educated. It does not seem to be the case that households with greater 
incidence of anemia are more likely to switch to DFS. The different treatments do not alter the composition of buyers in any important way either, with one exception; the "all store incentives" experiment seems to lead poorer households to purchase DFS than in the conditions without treatment. We need to take this finding with some caution, given the number of characteristics in the table, but it seems to be the one robust result. Based on the social marketing literature, one hypothesis we had was that the film could have been particularly effective on the type of families depicted in the movie, in this case a small nuclear family expecting their first child. We find no evidence for that.

The next two tables shed light on the mechanisms behind the effects, and suggest that although the movie and the store incentives had comparable impacts on purchase, the underlying reasons were very different. The movie informed households and led them to demand more double-fortified salt; the store incentives led shopkeepers to try to force households to buy it.

In Table 6 we provide more evidence from a survey that we conducted with our study households in each village on average 45 days after the store incentive experiments started- which was many months before the endline survey showing the results above. This earlier survey focused on salt adoption and purchase and was conducted in all the villages that were part of the store incentive experiments. In Table 7 , we show data that comes from a survey conducted with shopkeepers.

Column 1 of Table 6 mostly confirms the findings of Table 4, with one exception: it seems to suggest that even the flyer led to some adoption of DFS (3.9 percentage points). This is perhaps because the survey was conducted shortly after the flyer distribution (50 days on average, between 1 and 80 days depending on the village), and households were persuaded to buy DFS once, but then stopped.

The next few columns look at stated reasons for buying DFS. Interestingly, no one in the control group reports buying DFS because it prevents anemia. In contrast, in the movie group, $8.6 \%$ of the DFS buyers say that they buy it because it reduces anemia and the fraction of buyers who buy DFS because this is what they have always done, goes down. Thus, the movie succeeded in conveying its message.

Another sign that the movie changed households' information is that they report paying less for the DFS in the movie villages. There was a scene in the film where the price of ₹9 for the 
double-fortified salt was clearly shown. Looking at the distribution of reported prices (results not shown), we find that they are more likely to report paying ₹9 (the official price) and less likely to report 10 rupees. This is not confirmed by what the shopkeepers report in Table 7 , but it is plausible that generally people do not know exactly how much they pay for salt. Those who saw the movie know the price better.

On the other hand, in the "incentive for all kiranas" treatment, households who bought DFS are much more likely to report that this was the only salt available. This suggests that, rather than lowering the price (which does not change, see column 6 in Table 6) or selling the virtues of DFS (households are no more likely to buy it because it reduces anemia, but they are less likely to buy it because it contains iodine), the main marketing strategy of the shopkeeper was to push it on people by claiming he did not have anything else, even if he did. Note that this was not done by simply treating DFS as the default: the fraction of purchasers who buy DFS because it was what the shopkeeper handed them or what he recommended actually goes down in the store incentive treatments. Instead, the main margin of influence seems to be not giving customers a choice.

In Table 7 (columns 8 and 9) we see that although shopkeepers who received the incentives were more likely to carry and display DFS, and carried more of it, most of them also carry other iodized salt, as well as in some cases unbranded rock salt, and that these proportions are not affected by receiving the incentives.

The behavior of the other shopkeepers in villages where only one shopkeeper got the incentive is interesting. While the incentivized shop behaves exactly like the shops in villages where all shops got the incentive, shops that are not getting the incentive are more likely to carry other types of branded salt relative to the control group (where no one got incentives). This may be to attract consumers with variety. Recall that about half of the households that are given DFS for free still do not want to use it. If the incentivized shopkeeper is more likely to claim that DFS is all he has, some consumers who are really averse to it probably decide to go to another shop to buy a substitute. Shops that carry the alternative will thus increase their sales.

There may then be two reasons why the overall take-up of the salt does not change relative to the control group. First, the shopkeeper with incentives may stop trying to impose doublefortified salt, as a result of this kind of competitive pressure. Second, there may be a composition effect, with purchases of DFS going up in the store that gets the incentive and down in the stores 
that do not (over and above the sorting of the clients). The former explanation is not consistent with the data, since the probability of DFS purchasers saying that they got it because it was the only one available goes up even when only one store receives the incentive. Therefore, the latter explanation is likely: shopkeepers that did not receive the incentive may have helped spread rumors that the salt was not good for people's health in order to depress demand. Anecdotal reports suggest that this was indeed the case.

\section{Conclusion}

The promise of double-fortified salt to reduce anemia and increase productivity rests on two premises: that households will be willing to buy it and use it, even at a reduced price - or potentially for free - and that it is effective enough, at the levels of fortification that are stable and safe, to make a real difference 8

This paper addresses the first question. Double-fortified salt is a new product, with some characteristics that would positively influence adoption (it is clean and white, sold in a fancy packet with a trusted brand name) and some handicaps (people are generally reluctant to try new foods, there were some instances of food blackening early on). Moreover many people did not understand the links between salt and anemia, or between anemia and well being. Clearly, the basic marketing campaign conducted by the manufacturer at launch was completely ineffective at conveying why this salt should be purchased: two years after the introduction of the product, absent any additional information campaign, no one who buys DFS knows that it helps reduce anemia, or reports buying it because it is good for the health of household members.

Even when the salt is provided for free, only about half of households actually use it for cooking. When they have to buy it just below half price, with no other intervention, about $20 \%$ of households give it a try, but only $10 \%$ still use it after about three years.

Against this backdrop, this paper shows the power of a strong communication campaign, in the form of an entertaining movie that was seen by about $20 \%$ of the households in the village, in changing households' perception about the product. Consumption of doubled-fortified salt increased by 5.5 percentage points, an increase of $50 \%$ over the mean for households who have to buy the salt, and more than $10 \%$ over the mean usage among those who get it for free. Eight

8 In settings like schools where children have no choice about what they eat, only the second question is pertinent. 
percent of households who buy DFS at endline do report that they bought this salt because it helps fighting anemia (although that leaves 92\% who do so for other reasons), and they pay a lower price on average (as advertised in the movie).

The paper also highlights how powerful shopkeepers are in influencing what households do. A small increase in (all) retailer margins resulted in an increase in take-up at least as large as that caused by the movie screening. There is some ambiguity on how this was achieved. The retailers claim that they dropped the final price of the salt (very little). Village households do not report such a decline and instead claim that they bought the salt because it was the only one available. More generally, over half of the buyers of DFS report that they just bought what the shopkeeper gave them. On the other hand, when only one shopkeeper was given an incentive, the others seem to have reacted by being more likely to sell other types of salt. There was no increase in the overall take-up of DFS. Future research should investigate the impact of providing discounts to consumers versus providing them to shopkeepers, and, more generally, examine their potential as agents of change. 


\section{Tables}

Table 1: Balance Checks, BL Characteristics

\begin{tabular}{|c|c|c|c|c|c|c|c|c|c|c|}
\hline & $\begin{array}{c}\text { Female } \\
(1)\end{array}$ & $\begin{array}{l}\text { Age } \\
(2)\end{array}$ & $\begin{array}{c}\text { Elderly } \\
\text { (3) }\end{array}$ & $\begin{array}{c}\text { Anemic } \\
(4)\end{array}$ & $\begin{array}{c}\text { Severely } \\
\text { anemic } \\
\\
(5)\end{array}$ & $\begin{array}{l}\text { HB Concen- } \\
\text { tration } \\
\\
(6)\end{array}$ & $\begin{array}{l}\text { Consump } \\
\text { per capita } \\
\text { in the past } \\
30 \text { days (in } \\
\text { thous of } \\
\text { INR) } \\
(7)\end{array}$ & $\begin{array}{l}\text { HH head } \\
\text { completed } \\
\text { class } 5 \text { or } \\
\text { above } \\
(8)\end{array}$ & $\begin{array}{c}\text { Number of } \\
\text { HH } \\
\text { Members } \\
\\
(9)\end{array}$ & $\begin{array}{l}\text { HH includes } \\
\text { only } \\
\text { immediate } \\
\text { family } \\
\text { members } \\
(10)\end{array}$ \\
\hline Movie Experiment & $\begin{array}{c}0.005 \\
{[0.006]}\end{array}$ & $\begin{array}{l}-0.425 \\
{[0.335]}\end{array}$ & $\begin{array}{c}-0.004 \\
{[0.006]}\end{array}$ & $\begin{array}{c}0.006 \\
{[0.007]}\end{array}$ & $\begin{array}{l}-0.001 \\
{[0.002]}\end{array}$ & $\begin{array}{c}-0.102^{* *} \\
{[0.050]}\end{array}$ & $\begin{array}{c}0.021 \\
{[0.077]}\end{array}$ & $\begin{array}{l}0.048^{* *} \\
{[0.023]}\end{array}$ & $\begin{array}{l}-0.186 \\
{[0.298]}\end{array}$ & $\begin{array}{c}0.010 \\
{[0.016]}\end{array}$ \\
\hline Flyer Promotion Experiment & $\begin{array}{l}-0.003 \\
{[0.007]}\end{array}$ & $\begin{array}{l}-0.595 \\
{[0.422]}\end{array}$ & $\begin{array}{l}-0.010 \\
{[0.007]}\end{array}$ & $\begin{array}{c}0.000 \\
{[0.008]}\end{array}$ & $\begin{array}{l}-0.001 \\
{[0.002]}\end{array}$ & $\begin{array}{c}0.068 \\
{[0.057]}\end{array}$ & $\begin{array}{l}-0.040 \\
{[0.088]}\end{array}$ & $\begin{array}{l}-0.033 \\
{[0.026]}\end{array}$ & $\begin{array}{c}0.377 \\
{[0.310]}\end{array}$ & $\begin{array}{l}-0.013 \\
{[0.019]}\end{array}$ \\
\hline Store Incentive - All Kiranas & $\begin{array}{c}0.004 \\
{[0.008]}\end{array}$ & $\begin{array}{c}0.328 \\
{[0.418]}\end{array}$ & $\begin{array}{c}0.004 \\
{[0.007]}\end{array}$ & $\begin{array}{c}-0.020^{* *} \\
{[0.009]}\end{array}$ & $\begin{array}{c}-0.001 \\
{[0.002]}\end{array}$ & $\begin{array}{c}0.050 \\
{[0.063]}\end{array}$ & $\begin{array}{c}-0.066 \\
{[0.099]}\end{array}$ & $\begin{array}{c}-0.027 \\
{[0.028]}\end{array}$ & $\begin{array}{c}-0.229 \\
{[0.363]}\end{array}$ & $\begin{array}{c}0.011 \\
{[0.019]}\end{array}$ \\
\hline Store Incentive - 1 Kirana & $\begin{array}{c}0.003 \\
{[0.008]}\end{array}$ & $\begin{array}{c}0.093 \\
{[0.423]}\end{array}$ & $\begin{array}{c}0.004 \\
{[0.008]}\end{array}$ & $\begin{array}{c}0.001 \\
{[0.009]}\end{array}$ & $\begin{array}{c}0.002 \\
{[0.002]}\end{array}$ & $\begin{array}{l}-0.038 \\
{[0.063]}\end{array}$ & $\begin{array}{l}-0.090 \\
{[0.097]}\end{array}$ & $\begin{array}{c}0.017 \\
{[0.029]}\end{array}$ & $\begin{array}{l}-0.174 \\
{[0.408]}\end{array}$ & $\begin{array}{l}0.036^{*} \\
{[0.020]}\end{array}$ \\
\hline Free DFS Households & $\begin{array}{l}-0.011 \\
{[0.009]}\end{array}$ & $\begin{array}{c}-1.439^{* * *} \\
{[0.542]}\end{array}$ & $\begin{array}{c}-0.022^{* *} \\
{[0.010]}\end{array}$ & $\begin{array}{c}0.007 \\
{[0.011]}\end{array}$ & $\begin{array}{l}0.004^{*} \\
{[0.002]}\end{array}$ & $\begin{array}{l}-0.107 \\
{[0.065]}\end{array}$ & $\begin{array}{c}0.145 \\
{[0.131]}\end{array}$ & $\begin{array}{c}-0.078^{* *} \\
{[0.040]}\end{array}$ & $\begin{array}{l}-0.120 \\
{[0.558]}\end{array}$ & $\begin{array}{c}0.017 \\
{[0.026]}\end{array}$ \\
\hline Basic Treatment Mean within Treatment Group & 0.513 & 26.205 & 0.166 & 0.128 & 0.009 & 12.302 & 2.236 & $\begin{array}{l}0.563 \\
0.574\end{array}$ & $\begin{array}{l}8.726 \\
8.429\end{array}$ & $\begin{array}{l}0.224 \\
0.231\end{array}$ \\
\hline $\begin{array}{l}\text { Main Control Group Mean } \\
\text { Observations }\end{array}$ & $\begin{array}{l}0.515 \\
19998\end{array}$ & $\begin{array}{l}26.522 \\
19998\end{array}$ & $\begin{array}{l}0.182 \\
19998\end{array}$ & $\begin{array}{l}0.148 \\
17342\end{array}$ & $\begin{array}{l}0.008 \\
17342\end{array}$ & $\begin{array}{l}12.196 \\
17342\end{array}$ & $\begin{array}{l}2.074 \\
19852\end{array}$ & $\begin{array}{l}0.574 \\
18677\end{array}$ & $\begin{array}{l}8.429 \\
19997\end{array}$ & $\begin{array}{l}0.231 \\
19976\end{array}$ \\
\hline
\end{tabular}

$1 * \mathrm{p}<0.10, * * \mathrm{p}<0.05, * * * \mathrm{p}<0.01$. Standard errors in brackets.

2 Note: The sample excludes the control group for the main treatment. Regression includes block-fixed effects. Regressors not reported include a dummy for Free DFS Villages and a dummy for Non-Store Incentive households within the main treatment villages. Standard errors are clustered at the village level for individual characteristics and at the household level for household characteristics. Intermediate family members include household head, wife/husband of household, and children of household head. The variable for consumption is measured in rupees. 
Table 2: Individual-level and Household-Level Attrition by Experiment Type

\begin{tabular}{lcc}
\hline & Respondent & HH Lost to \\
& Lost to & Attrition since \\
& Attrition since & BL \\
& $(1)$ & $(2)$ \\
\hline Movie Experiment & -0.009 & 0.004 \\
& {$[0.012]$} & {$[0.010]$} \\
Flyer Promotion Experiment & 0.013 & -0.007 \\
& {$[0.013]$} & {$[0.012]$} \\
Store Incentive - All Kiranas & 0.020 & 0.013 \\
& {$[0.013]$} & {$[0.013]$} \\
Store Incentive - 1 Kirana & 0.023 & 0.005 \\
& {$[0.015]$} & {$[0.014]$} \\
Free DFS Households & $-0.032^{* *}$ & -0.015 \\
& {$[0.016]$} & {$[0.011]$} \\
\hline Basic Treatment Mean within Treatment Group & 0.206 & 0.081 \\
Main Control Group Mean & 0.193 & 0.064 \\
Observations & 20315 & 3002 \\
\hline
\end{tabular}

$1 * \mathrm{p}<0.10, * * \mathrm{p}<0.05,{ }^{* * *} \mathrm{p}<0.01$. Standard errors in brackets. ${ }^{2}$ Note: The sample excludes the control group for the main treatment. Regression includes block-fixed effects. Regressors not reported include a dummy for Free DFS Villages and a dummy for Non-Store Incentive households within the main treatment villages. Standard errors are clustered at the village level for individual characteristics and at the household level for household characteristics. 
Table 3: Characteristics of those Lost to Attrition since BL

\begin{tabular}{|c|c|c|c|c|c|c|c|c|c|c|}
\hline & Female & Age & Elderly & Anemic & $\begin{array}{c}\text { Severely } \\
\text { anemic } \\
\\
(5)\end{array}$ & $\begin{array}{c}\text { HB } \\
\text { Concentration } \\
\text { (6) }\end{array}$ & $\begin{array}{l}\text { Consump per } \\
\text { capita in the } \\
\text { past } 30 \text { days } \\
\text { (in thous of } \\
\text { INR) } \\
\text { (7) }\end{array}$ & $\begin{array}{l}\text { HH head } \\
\text { completed } \\
\text { class } 5 \text { or } \\
\text { above } \\
(8)\end{array}$ & $\begin{array}{c}\text { Number of HH } \\
\text { Members } \\
\text { (9) }\end{array}$ & $\begin{array}{c}\text { HH includes } \\
\text { only } \\
\text { immediate } \\
\text { family } \\
\text { members } \\
(10)\end{array}$ \\
\hline \multirow[t]{2}{*}{ Resp lost to attrition since $\mathrm{BL}$} & $\begin{array}{c}-0.037^{* * *} \\
{[0.009]}\end{array}$ & $\begin{array}{l}0.928^{* *} \\
{[0.456]}\end{array}$ & $\begin{array}{l}-0.005 \\
{[0.008]}\end{array}$ & $\begin{array}{c}-0.037^{* * *} \\
{[0.008]}\end{array}$ & $\begin{array}{l}0.005^{* *} \\
{[0.002]}\end{array}$ & $\begin{array}{c}0.022 \\
{[0.050]}\end{array}$ & $\begin{array}{l}-0.054 \\
{[0.052]}\end{array}$ & $\begin{array}{l}-0.007 \\
{[0.016]}\end{array}$ & $\begin{array}{l}-0.330 \\
{[0.211]}\end{array}$ & $\begin{array}{l}-0.010 \\
{[0.012]}\end{array}$ \\
\hline & \multicolumn{10}{|c|}{ Characteristics of Those Lost to Attrition by Experiment Type } \\
\hline $\begin{array}{l}\text { Movie Experiment } * \\
\text { Respondent lost to attrition since BL }\end{array}$ & $\begin{array}{l}0.035^{*} \\
{[0.020]}\end{array}$ & $\begin{array}{l}2.457^{* *} \\
{[0.949]}\end{array}$ & $\begin{array}{l}0.033^{* *} \\
{[0.016]}\end{array}$ & $\begin{array}{c}-0.043^{* * *} \\
{[0.016]}\end{array}$ & $\begin{array}{l}0.010^{*} \\
{[0.005]}\end{array}$ & $\begin{array}{l}-0.071 \\
{[0.102]}\end{array}$ & $\begin{array}{l}0.234^{* *} \\
{[0.116]}\end{array}$ & $\begin{array}{c}0.042 \\
{[0.034]}\end{array}$ & $\begin{array}{l}-0.735^{*} \\
{[0.439]}\end{array}$ & $\begin{array}{c}0.027 \\
{[0.027]}\end{array}$ \\
\hline $\begin{array}{l}\text { Flyer Promotion } \\
\text { Experiment * Respondent lost to attrition since BL }\end{array}$ & $\begin{array}{l}-0.014 \\
{[0.022]}\end{array}$ & $\begin{array}{c}-2.172^{*} \\
{[1.115]}\end{array}$ & $\begin{array}{c}-0.044^{* *} \\
{[0.018]}\end{array}$ & $\begin{array}{c}0.021 \\
{[0.016]}\end{array}$ & $\begin{array}{c}0.003 \\
{[0.006]}\end{array}$ & $\begin{array}{c}0.057 \\
{[0.109]}\end{array}$ & $\begin{array}{c}0.317^{* * *} \\
{[0.106]}\end{array}$ & $\begin{array}{c}0.034 \\
{[0.039]}\end{array}$ & $\begin{array}{c}0.550 \\
{[0.436]}\end{array}$ & $\begin{array}{l}-0.032 \\
{[0.031]}\end{array}$ \\
\hline $\begin{array}{l}\text { Store Incentive - } \\
\text { All Kiranas * Respondent lost to attrition since BL }\end{array}$ & $\begin{array}{c}0.060^{* * *} \\
{[0.021]}\end{array}$ & $\begin{array}{l}-0.608 \\
{[1.133]}\end{array}$ & $\begin{array}{l}-0.006 \\
{[0.020]}\end{array}$ & $\begin{array}{l}-0.028 \\
{[0.020]}\end{array}$ & $\begin{array}{c}0.007 \\
{[0.006]}\end{array}$ & $\begin{array}{l}-0.091 \\
{[0.118]}\end{array}$ & $\begin{array}{l}-0.090 \\
{[0.135]}\end{array}$ & $\begin{array}{l}-0.004 \\
{[0.040]}\end{array}$ & $\begin{array}{c}0.346 \\
{[0.510]}\end{array}$ & $\begin{array}{c}0.001 \\
{[0.030]}\end{array}$ \\
\hline $\begin{array}{l}\text { Store Incentive - } 1 \\
\text { Kirana * Respondent lost to attrition since BL }\end{array}$ & $\begin{array}{l}-0.008 \\
{[0.023]}\end{array}$ & $\begin{array}{c}0.301 \\
{[1.131]}\end{array}$ & $\begin{array}{l}-0.002 \\
{[0.019]}\end{array}$ & $\begin{array}{l}-0.044^{*} \\
{[0.022]}\end{array}$ & $\begin{array}{l}0.011^{* *} \\
{[0.006]}\end{array}$ & $\begin{array}{c}0.002 \\
{[0.127]}\end{array}$ & $\begin{array}{l}-0.003 \\
{[0.134]}\end{array}$ & $\begin{array}{l}-0.024 \\
{[0.041]}\end{array}$ & $\begin{array}{c}0.694 \\
{[0.523]}\end{array}$ & $\begin{array}{l}-0.024 \\
{[0.030]}\end{array}$ \\
\hline $\begin{array}{l}\text { Free DFS Households } \\
{ }^{*} \text { Respondent lost to attrition since BL }\end{array}$ & $\begin{array}{l}-0.027 \\
{[0.032]}\end{array}$ & $\begin{array}{c}1.813 \\
{[1.659]}\end{array}$ & $\begin{array}{c}0.022 \\
{[0.030]}\end{array}$ & $\begin{array}{l}-0.001 \\
{[0.030]}\end{array}$ & $\begin{array}{l}-0.002 \\
{[0.007]}\end{array}$ & $\begin{array}{l}-0.130 \\
{[0.177]}\end{array}$ & $\begin{array}{c}-0.072 \\
{[0.169]}\end{array}$ & $\begin{array}{l}-0.013 \\
{[0.054]}\end{array}$ & $\begin{array}{l}-0.855^{*} \\
{[0.505]}\end{array}$ & $\begin{array}{c}0.020 \\
{[0.040]}\end{array}$ \\
\hline $\begin{array}{l}\text { Resp lost to } \\
\text { attrition since BL }\end{array}$ & $\begin{array}{l}-0.039 \\
{[0.024]}\end{array}$ & $\begin{array}{l}1.509 \\
{[1.225]}\end{array}$ & $\begin{array}{c}0.020 \\
{[0.020]}\end{array}$ & $\begin{array}{l}-0.012 \\
{[0.021]}\end{array}$ & $\begin{array}{l}-0.006 \\
{[0.005]}\end{array}$ & $\begin{array}{c}0.017 \\
{[0.135]}\end{array}$ & $\begin{array}{c}-0.267^{* *} \\
{[0.127]}\end{array}$ & $\begin{array}{l}-0.054 \\
{[0.048]}\end{array}$ & $\begin{array}{l}-0.783 \\
{[0.588]}\end{array}$ & $\begin{array}{c}0.015 \\
{[0.037]}\end{array}$ \\
\hline Observations & 19993 & 19993 & 19993 & 17338 & 17338 & 17338 & 19847 & 18674 & 19992 & 19971 \\
\hline
\end{tabular}

$1 * \mathrm{p}<0.10, * * \mathrm{p}<0.05, * * * \mathrm{p}<0.01$. Standard errors in brackets.

2 Note: The sample excludes the control group for the main treatment. Regression includes block-fixed effects. Regressors not reported include dummies for all the treatment groups (without the interactions), as well as a dummy for Free DFS Villages and a dummy for Non-Store Incentive households within the

main treatment villages. Also not reported is the interaction between Currently or Previously Use DFS and Non-Store Incentive HHs, as well as the interaction between Currently or Previously Use DFS and Free DFS Villages. Standard errors are clustered at the village level for individual characteristics and at the

household level for household characteristics. The variable for consumption is measured in rupees. 
Table 4: Take Up Regressions

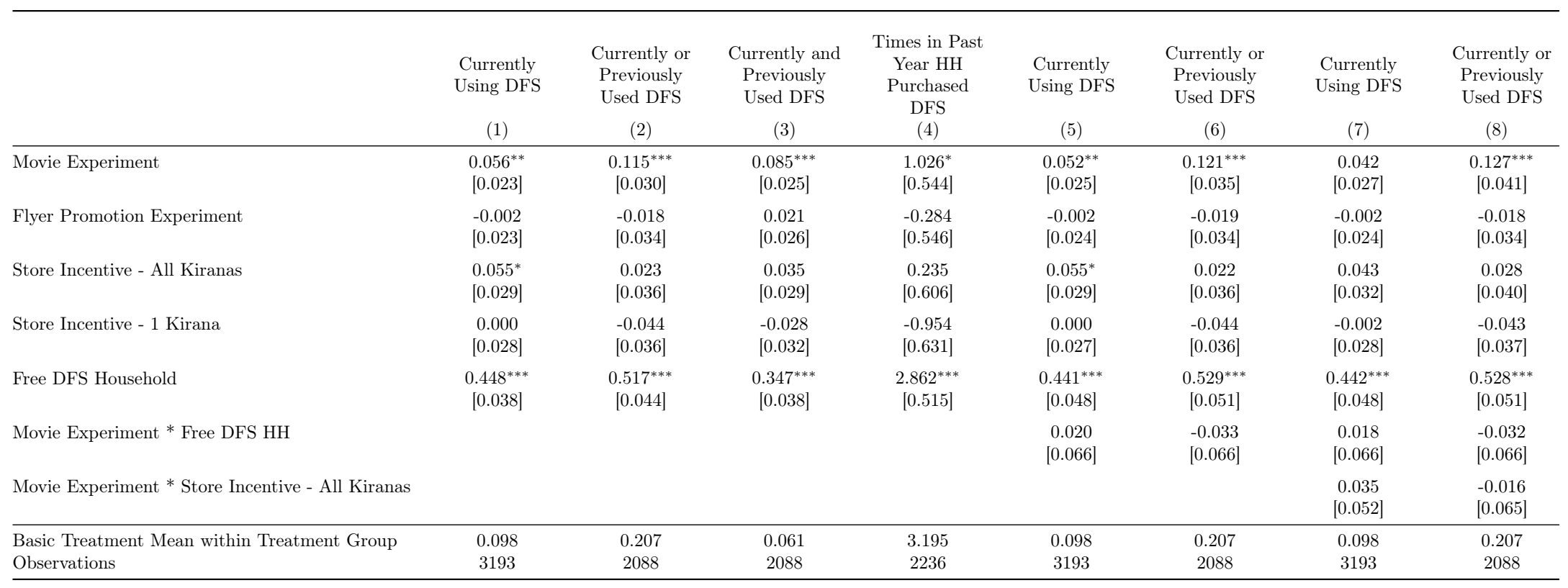

$1 * \mathrm{p}<0.10, * * \mathrm{p}<0.05, * * * \mathrm{p}<0.01$. Standard errors in brackets.

2 Note: The sample excludes the control group for the main treatment. Regression includes block-fixed effects. Regressors not reported include a dummy

for Free DFS Villages and a dummy for Non-Store Incentive households within the main treatment villages. Standard errors are clustered at the village level. 
Table 5: Household Characteristics of Current DFS Users

\begin{tabular}{|c|c|c|c|c|c|c|c|c|c|c|}
\hline & $\begin{array}{c}\text { Total } \\
\text { number of } \\
\text { females in } \\
\text { HH } \\
\text { (1) }\end{array}$ & $\begin{array}{l}\text { Average age } \\
\text { of HH } \\
\text { members } \\
(2)\end{array}$ & $\begin{array}{c}\text { Total } \\
\text { number of } \\
\text { elderly HH } \\
\text { members } \\
\text { (3) }\end{array}$ & $\begin{array}{c}\text { Total } \\
\text { number of } \\
\text { anemic HH } \\
\text { members } \\
\text { (4) }\end{array}$ & $\begin{array}{c}\text { Average HB } \\
\text { Conc of HH } \\
\text { Members } \\
(5)\end{array}$ & $\begin{array}{l}\text { Consump } \\
\text { per capita } \\
\text { in the past } \\
30 \text { days (in } \\
\text { thous of } \\
\text { INR) } \\
(6)\end{array}$ & $\begin{array}{c}\text { HH head } \\
\text { completed } \\
\text { class } 5 \text { or } \\
\text { above } \\
(7)\end{array}$ & $\begin{array}{c}\text { Female HH } \\
\text { head } \\
\text { completed } \\
\text { class } 5 \text { or } \\
\text { above } \\
(8)\end{array}$ & $\begin{array}{c}\text { Total } \\
\text { number of } \\
\text { HH } \\
\text { members } \\
\text { (9) }\end{array}$ & $\begin{array}{c}\text { HH includes } \\
\text { only } \\
\text { immediate } \\
\text { family } \\
\text { members } \\
(10)\end{array}$ \\
\hline Movie Experiment * Currently Use DFS & $\begin{array}{c}0.371 \\
{[0.347]}\end{array}$ & $\begin{array}{c}-0.787 \\
{[1.006]}\end{array}$ & $\begin{array}{c}0.072 \\
{[0.104]}\end{array}$ & $\begin{array}{l}-0.050 \\
{[0.157]}\end{array}$ & $\begin{array}{c}0.115 \\
{[0.096]}\end{array}$ & $\begin{array}{c}-0.315 \\
0.199]\end{array}$ & $\begin{array}{c}-0.005 \\
{[0.052]}\end{array}$ & $\begin{array}{c}0.077 \\
{[0.047]}\end{array}$ & $\begin{array}{c}0.624 \\
{[0.598]}\end{array}$ & $\begin{array}{c}-0.035 \\
{[0.042]}\end{array}$ \\
\hline Flyer Promotion Experiment $*$ Currently Use DFS & $\begin{array}{l}-0.578 \\
{[0.372]}\end{array}$ & $\begin{array}{c}0.954 \\
{[0.967]}\end{array}$ & $\begin{array}{c}-0.039 \\
{[0.103]}\end{array}$ & $\begin{array}{l}-0.047 \\
{[0.137]}\end{array}$ & $\begin{array}{c}0.079 \\
{[0.104]}\end{array}$ & $\begin{array}{l}-0.010 \\
{[0.205]}\end{array}$ & $\begin{array}{c}0.013 \\
{[0.052]}\end{array}$ & $\begin{array}{l}-0.006 \\
{[0.047]}\end{array}$ & $\begin{array}{l}-0.953 \\
{[0.630]}\end{array}$ & $\begin{array}{c}0.010 \\
{[0.046]}\end{array}$ \\
\hline Store Incentive - All Kiranas * Currently Use DFS & $\begin{array}{l}-0.532 \\
{[0.453]}\end{array}$ & $\begin{array}{l}-0.439 \\
{[1.108]}\end{array}$ & $\begin{array}{l}-0.154 \\
{[0.114]}\end{array}$ & $\begin{array}{l}-0.207 \\
{[0.209]}\end{array}$ & $\begin{array}{c}0.103 \\
{[0.112]}\end{array}$ & $\begin{array}{c}-0.206 \\
{[0.270]}\end{array}$ & $\begin{array}{l}-0.076 \\
{[0.064]}\end{array}$ & $\begin{array}{l}-0.050 \\
{[0.057]}\end{array}$ & $\begin{array}{c}-0.696 \\
{[0.797]}\end{array}$ & $\begin{array}{c}0.045 \\
{[0.051]}\end{array}$ \\
\hline Store Incentive - 1 Kirana $*$ Currently Use DFS & $\begin{array}{c}-0.856^{*} \\
{[0.437]}\end{array}$ & $\begin{array}{c}1.071 \\
{[1.272]}\end{array}$ & $\begin{array}{l}-0.147 \\
{[0.136]}\end{array}$ & $\begin{array}{l}-0.227 \\
{[0.223]}\end{array}$ & $\begin{array}{c}0.111 \\
{[0.123]}\end{array}$ & $\begin{array}{c}-0.244 \\
{[0.278]}\end{array}$ & $\begin{array}{l}-0.045 \\
{[0.065]}\end{array}$ & $\begin{array}{l}-0.044 \\
{[0.058]}\end{array}$ & $\begin{array}{l}-1.052 \\
{[0.770]}\end{array}$ & $\begin{array}{c}0.030 \\
{[0.061]}\end{array}$ \\
\hline Free DFS Household * Currently Use DFS & $\begin{array}{l}-0.232 \\
{[0.487]}\end{array}$ & $\begin{array}{c}0.869 \\
{[1.678]}\end{array}$ & $\begin{array}{c}0.008 \\
{[0.153]}\end{array}$ & $\begin{array}{c}0.365 \\
{[0.227]}\end{array}$ & $\begin{array}{c}-0.149 \\
{[0.168 \mid}\end{array}$ & $\begin{array}{c}0.445 \\
{[0.318]}\end{array}$ & $\begin{array}{c}0.010 \\
{[0.076]}\end{array}$ & $\begin{array}{c}0.030 \\
{[0.073]}\end{array}$ & $\begin{array}{l}-0.187 \\
{[0.891]}\end{array}$ & $\begin{array}{c}0.001 \\
{[0.077]}\end{array}$ \\
\hline Currently Using DFS & $\begin{array}{l}0.821^{*} \\
{[0.465]}\end{array}$ & $\begin{array}{l}-0.050 \\
{[1.378]}\end{array}$ & $\begin{array}{c}0.116 \\
{[0.144]}\end{array}$ & $\begin{array}{c}0.128 \\
{[0.222]}\end{array}$ & $\begin{array}{l}-0.041 \\
{[0.139]}\end{array}$ & $\begin{array}{c}0.253 \\
{[0.280]}\end{array}$ & $\begin{array}{l}0.134^{*} \\
{[0.075]}\end{array}$ & $\begin{array}{c}0.070 \\
{[0.062]}\end{array}$ & $\begin{array}{c}0.973 \\
{[0.832]}\end{array}$ & $\begin{array}{l}-0.037 \\
{[0.063]}\end{array}$ \\
\hline Basic Treatment Mean within Treatment Group & 3.662 & 28.142 & 1.221 & 0.794 & 12.277 & 2.491 & 0.555 & 0.133 & 7.176 & 0.324 \\
\hline Main Control Group Mean & 3.667 & 28.673 & 1.263 & 0.923 & 12.228 & 2.266 & 0.545 & 0.216 & 7.104 & 0.314 \\
\hline Observations & 3193 & 3193 & 3193 & 3152 & 3152 & 3174 & 2990 & 2841 & 3193 & 3192 \\
\hline
\end{tabular}

$1 * \mathrm{p}<0.10, * * \mathrm{p}<0.05, * * * \mathrm{p}<0.01$. Standard errors in brackets.

2 Note: The sample excludes the control group for the main treatment. Regression includes block-fixed effects.Regressors not reported include dummies for all the treatment groups (without the interactions), as well as a dummy for Free DFS Villages and a dummy for Non-Store Incentive households within the main treatment villages. Also not reported is the interaction between Currently or Previously Use DFS and Non-Store Incentive HHs, as well as the interaction between Currently or Previously Use DFS and Free DFS Villages. The variable female head of household is defined as either the wife of the head of the household or the head of the household. If there were multiple female heads for the household, then the highest education level out of all the female household heads was used. Standard errors are clustered at the village level. The variable for consumption is measured in rupees. 
Table 6: HH Take-Up Results from Store Incentive Experiment

\begin{tabular}{|c|c|c|c|c|c|c|c|c|c|}
\hline & $\begin{array}{l}\text { Currently } \\
\text { Use DFS } \\
\\
\text { (1) }\end{array}$ & $\begin{array}{l}\text { Selected } \\
\text { DFS } \\
\text { because } \\
\text { contains } \\
\text { iron or } \\
\text { because it } \\
\text { reduces } \\
\text { anemia } \\
(2)\end{array}$ & $\begin{array}{l}\text { Selected } \\
\text { DFS } \\
\text { because } \\
\text { contains } \\
\text { iodine } \\
\\
\text { (3) }\end{array}$ & $\begin{array}{l}\text { Selected } \\
\text { DFS } \\
\text { because of } \\
\text { taste } \\
\\
\text { (4) }\end{array}$ & $\begin{array}{c}\text { Selected } \\
\text { DFS } \\
\text { because of } \\
\text { clean, white } \\
\text { appearance } \\
(5)\end{array}$ & $\begin{array}{l}\text { Selected } \\
\text { DFS } \\
\text { because } \\
\text { always buy } \\
\text { the same } \\
\text { thing } \\
(6)\end{array}$ & $\begin{array}{l}\text { Selected } \\
\text { DFS } \\
\text { because no } \\
\text { other salt } \\
\text { available } \\
\\
(7)\end{array}$ & $\begin{array}{l}\text { Store owner } \\
\text { gave or } \\
\text { recommend } \\
\text { DFS to } \\
\text { respondent } \\
\text { (8) }\end{array}$ & $\begin{array}{l}\text { Amount } \\
\text { paid for } 1 \\
\text { packet of } \\
\text { DFS } \\
\text { (9) }\end{array}$ \\
\hline Movie Experiment & $\begin{array}{c}0.049^{* *} \\
{[0.024]}\end{array}$ & $\begin{array}{c}0.086^{* *} \\
{[0.039]}\end{array}$ & $\begin{array}{c}0.011 \\
{[0.033]}\end{array}$ & $\begin{array}{c}0.019 \\
{[0.043]}\end{array}$ & $\begin{array}{c}0.001 \\
{[0.036]}\end{array}$ & $\begin{array}{c}-0.074^{* * *} \\
{[0.028]}\end{array}$ & $\begin{array}{c}0.042 \\
{[0.057]}\end{array}$ & $\begin{array}{l}-0.093 \\
{[0.061]}\end{array}$ & $\begin{array}{c}-0.398^{* *} \\
{[0.182]}\end{array}$ \\
\hline Flyer Promotion Experiment & $\begin{array}{l}0.039^{*} \\
{[0.023]}\end{array}$ & $\begin{array}{l}-0.045 \\
{[0.044]}\end{array}$ & $\begin{array}{c}-0.012 \\
{[0.046]}\end{array}$ & $\begin{array}{l}-0.003 \\
{[0.055]}\end{array}$ & $\begin{array}{l}-0.081 \\
{[0.051]}\end{array}$ & $\begin{array}{l}0.055^{*} \\
{[0.032]}\end{array}$ & $\begin{array}{c}0.068 \\
{[0.069]}\end{array}$ & $\begin{array}{l}-0.113 \\
{[0.070]}\end{array}$ & $\begin{array}{c}0.478^{* * *} \\
{[0.182]}\end{array}$ \\
\hline Store Incentive - All Kiranas & $\begin{array}{c}0.078^{* * *} \\
{[0.030]}\end{array}$ & $\begin{array}{l}-0.000 \\
{[0.039]}\end{array}$ & $\begin{array}{c}-0.085^{* *} \\
{[0.040]}\end{array}$ & $\begin{array}{l}-0.013 \\
{[0.045]}\end{array}$ & $\begin{array}{c}0.040 \\
{[0.045]}\end{array}$ & $\begin{array}{l}-0.038 \\
{[0.033]}\end{array}$ & $\begin{array}{l}0.137^{* *} \\
{[0.057]}\end{array}$ & $\begin{array}{l}-0.087 \\
{[0.070]}\end{array}$ & $\begin{array}{c}0.163 \\
{[0.199]}\end{array}$ \\
\hline Store Incentive - 1 Kirana & $\begin{array}{l}-0.031 \\
{[0.022]}\end{array}$ & $\begin{array}{c}0.057 \\
{[0.055]}\end{array}$ & $\begin{array}{c}0.023 \\
{[0.055]}\end{array}$ & $\begin{array}{c}0.022 \\
{[0.060]}\end{array}$ & $\begin{array}{c}-0.028 \\
{[0.060]}\end{array}$ & $\begin{array}{c}-0.011 \\
{[0.043]}\end{array}$ & $\begin{array}{c}0.117 \\
{[0.072]}\end{array}$ & $\begin{array}{c}-0.147^{*} \\
{[0.076]}\end{array}$ & $\begin{array}{c}0.078 \\
{[0.160]}\end{array}$ \\
\hline $\begin{array}{l}\text { Basic Treatment Mean within Treatment Group } \\
\text { Observations }\end{array}$ & $\begin{array}{c}0.099 \\
4862\end{array}$ & $\begin{array}{c}0.000 \\
636\end{array}$ & $\begin{array}{c}0.033 \\
636\end{array}$ & $\begin{array}{c}0.083 \\
636\end{array}$ & $\begin{array}{c}0.116 \\
636\end{array}$ & $\begin{array}{c}0.033 \\
636\end{array}$ & $\begin{array}{c}0.157 \\
636\end{array}$ & $\begin{array}{c}0.463 \\
636\end{array}$ & $\begin{array}{l}8.135 \\
608\end{array}$ \\
\hline
\end{tabular}

$1 * \mathrm{p}<0.10, * * \mathrm{p}<0.05, * * * \mathrm{p}<0.01$. Standard errors in brackets.

2 Note: The sample excludes the control group for the main treatment, Free DFS households, and all households within the main treatment that were not part of the store incentive experiment. Columns 2-10 include only houses that were currently using DFS. Regression includes block-fixed effects. A dummy for free DFS villages was included in the regressions, but the coefficient is not reported. The amount paid for 1 packet of DFS is measured in rupees. 
Table 7: Store Take-Up Results from Store Incentive Experiment

\begin{tabular}{|c|c|c|c|c|c|c|c|c|c|}
\hline & $\begin{array}{l}\text { Ever sold } \\
\text { DFS } \\
\text { (1) }\end{array}$ & $\begin{array}{c}\text { DFS } \\
\text { currently } \\
\text { instock } \\
(2)\end{array}$ & $\begin{array}{l}\text { Number of } \\
1 \text { kg DFS } \\
\text { packets in } \\
\text { stock } \\
\text { (3) }\end{array}$ & $\begin{array}{c}\text { Amount at } \\
\text { which store } \\
\text { sells } 1 \mathrm{~kg} \text { of } \\
\text { DFS } \\
(4)\end{array}$ & $\begin{array}{l}\text { Amount } \\
\text { paid for } 1 \\
\mathrm{~kg} \text { of DFS } \\
\text { (5) }\end{array}$ & $\begin{array}{c}\text { Profit from } \\
1 \mathrm{~kg} \text { of DFS } \\
\text { (6) }\end{array}$ & $\begin{array}{c}\text { DFS } \\
\text { displayed in } \\
\text { store } \\
\\
(7)\end{array}$ & $\begin{array}{l}\text { Sell Other } \\
\text { Iodized Salt } \\
\text { (Not } \\
\text { Including } \\
\text { DFS) } \\
\text { (8) }\end{array}$ & $\begin{array}{c}\text { Sell } \\
\text { unbranded } \\
\text { rock salt } \\
(9)\end{array}$ \\
\hline Movie Experiment & $\begin{array}{l}-0.009 \\
{[0.031]}\end{array}$ & $\begin{array}{l}-0.060^{*} \\
{[0.033]}\end{array}$ & $\begin{array}{c}1.456 \\
{[3.207]}\end{array}$ & $\begin{array}{c}0.039 \\
{[0.050]}\end{array}$ & $\begin{array}{l}0.175^{*} \\
{[0.099]}\end{array}$ & $\begin{array}{l}-0.141 \\
{[0.107]}\end{array}$ & $\begin{array}{l}-0.035 \\
{[0.031]}\end{array}$ & $\begin{array}{l}-0.024 \\
{[0.022]}\end{array}$ & $\begin{array}{c}0.011 \\
{[0.034]}\end{array}$ \\
\hline Flyer Promotion Experiment & $\begin{array}{l}-0.031 \\
{[0.033]}\end{array}$ & $\begin{array}{l}-0.003 \\
{[0.039]}\end{array}$ & $\begin{array}{c}3.192 \\
{[2.984]}\end{array}$ & $\begin{array}{c}0.002 \\
{[0.041]}\end{array}$ & $\begin{array}{c}0.125 \\
{[0.117]}\end{array}$ & $\begin{array}{l}-0.119 \\
{[0.119]}\end{array}$ & $\begin{array}{l}-0.006 \\
{[0.039]}\end{array}$ & $\begin{array}{c}0.019 \\
{[0.024]}\end{array}$ & $\begin{array}{c}0.008 \\
{[0.034]}\end{array}$ \\
\hline Store Incentive - All Kiranas & $\begin{array}{l}0.074^{* *} \\
{[0.033]}\end{array}$ & $\begin{array}{c}0.190^{* * *} \\
{[0.040]}\end{array}$ & $\begin{array}{c}10.452^{* * *} \\
{[3.259]}\end{array}$ & $\begin{array}{c}-0.106^{* *} \\
{[0.051]}\end{array}$ & $\begin{array}{c}-1.228^{* * *} \\
{[0.123]}\end{array}$ & $\begin{array}{c}1.129^{* * *} \\
{[0.126]}\end{array}$ & $\begin{array}{c}0.143^{* * *} \\
{[0.041]}\end{array}$ & $\begin{array}{c}0.001 \\
{[0.028]}\end{array}$ & $\begin{array}{l}-0.011 \\
{[0.044]}\end{array}$ \\
\hline Store Incentive - 1 Kirana & $\begin{array}{l}-0.022 \\
{[0.032]}\end{array}$ & $\begin{array}{l}-0.011 \\
{[0.037]}\end{array}$ & $\begin{array}{l}-0.662 \\
{[2.524]}\end{array}$ & $\begin{array}{l}-0.048 \\
{[0.043]}\end{array}$ & $\begin{array}{c}0.071 \\
{[0.069]}\end{array}$ & $\begin{array}{l}-0.101 \\
{[0.081]}\end{array}$ & $\begin{array}{l}-0.018 \\
{[0.042]}\end{array}$ & $\begin{array}{l}0.043^{*} \\
{[0.024]}\end{array}$ & $\begin{array}{l}-0.065^{*} \\
{[0.039]}\end{array}$ \\
\hline Store Incentive - 1 Kirana $*$ Store Chosen for Incentive & $\begin{array}{c}0.050 \\
{[0.070]}\end{array}$ & $\begin{array}{l}0.143^{* *} \\
{[0.073]}\end{array}$ & $\begin{array}{c}4.296 \\
{[3.639]}\end{array}$ & $\begin{array}{l}-0.099 \\
{[0.080]}\end{array}$ & $\begin{array}{c}-1.219^{* * *} \\
{[0.341]}\end{array}$ & $\begin{array}{c}1.176^{* * *} \\
{[0.357]}\end{array}$ & $\begin{array}{l}0.217^{* *} \\
{[0.096]}\end{array}$ & $\begin{array}{l}-0.047 \\
{[0.053]}\end{array}$ & $\begin{array}{c}0.093 \\
{[0.078]}\end{array}$ \\
\hline $\begin{array}{l}\text { Basic Treatment Mean within Treatment Group } \\
\text { Observations }\end{array}$ & $\begin{array}{l}0.710 \\
1532\end{array}$ & $\begin{array}{l}0.314 \\
1316\end{array}$ & $\begin{array}{l}5.896 \\
1447\end{array}$ & $\begin{array}{l}9.197 \\
1074\end{array}$ & $\begin{array}{c}7.641 \\
593\end{array}$ & $\begin{array}{l}1.548 \\
590\end{array}$ & $\begin{array}{l}0.211 \\
1084\end{array}$ & $\begin{array}{l}0.860 \\
1316\end{array}$ & $\begin{array}{l}0.186 \\
1316\end{array}$ \\
\hline
\end{tabular}

$1 * \mathrm{p}<0.10, * * \mathrm{p}<0.05, * * * \mathrm{p}<0.01$. Standard errors in brackets.

${ }^{2}$ Note: The sample excludes the control group for the main treatment, Free DFS households, and all households within the main treatment that were not part of the store incentive experiment. Regression includes block-fixed effects. A dummy for free DFS villages was included in the regressions, but the coefficient is not reported. The amounts for Columns 4-6 are measured in rupees. 


\section{Appendix}

Appendix 1. Timeline of Activities

\begin{tabular}{lll}
\hline Start & End & Activity \\
\hline May 2011 & March 2012 & Baseline Survey \\
\hline October 2011 & November 2011 & Pricing Experiment \\
\hline August 2012 & May 2015 & Main Experiment: DFS Sales \\
\hline February 2013 & October 2013 & Monitoring Survey \\
\hline May 2013 & May 2015 & Free DFS Experiment \\
\hline August 2013 & December 2013 & Retailer Incentive Experiment \\
\hline October 2013 & February 2014 & Store \& Household Take-Up Surveys \\
\hline October 2013 & December 2013 & Movie Experiment \\
\hline October 2013 & November 2013 & Flyer Experiment \\
\hline July 2014 & February 2015 & Endline Survey \\
\hline The Pricing Experiment was conducted in Behea block with separate villages.
\end{tabular}




\section{References}

Ashraf, N., O. Bandiera, and K. Jack (2012). No margin, no mission. A Field Experiment on Incentives for Pro-Social Tasks, CEPR Discussion Papers 8834.

Baltussen, R., C. Knai, and M. Sharan (2004). Iron fortification and iron supplementation are cost-effective interventions to reduce iron deficiency in four subregions of the world. The Journal of Nutrition 134(10), $2678-2684$.

Banerjee, A., S. Barnhardt, and E. Duflo (2013). Nutrition, iron deficiency anemia, and the demand for ironfortified salt: Evidence from an experiment in rural Bihar. In Discoveries in the Economics of Aging, pp. 343-384. University of Chicago Press.

Banerjee, A., E. Duflo, and R. Glennerster (2011). Is Decentralized Iron Fortification a Feasible Option to Fight Anemia Among the Poorest? In Explorations in the Economics of Aging, pp. 317-344. University of Chicago Press.

Bhutta, Z. A., R. A. Salam, and J. K. Das (2013). Meeting the challenges of micronutrient malnutrition in the developing world. British Medical Bulletin 106(1), 7-17.

Brahmam, G., K. Nair, A. Laxmaiah, C. Gal Reddy, S. Ranganathan, M. Vishnuvardhana Rao, A. Naidu, K. Vijayaraghavan, B. Sivakumar, K. Krishanaswamy, et al. (2000). Community trials with iron and iodine fortified salt (double fortified salt). In Proceedings of the 8th World Salt Symposium, Volume 2, pp. 955-960. Amsterdam: Elsevier.

de Benoist, B., E. McLean, I. Egli, and M. Cogswell (2008). Worldwide Prevalence of Anaemia 1993-2005: WHO Global Database of Anaemia. Technical report, World Health Organization Geneva.

Dupas, P. (2009). What matters (and what does not) in households' decision to invest in malaria prevention? The American Economic Review 99(2), 224-230.

Gunhild, B. and B. Zia (2013). Harnessing emotional connections to improve financial decisions: Evaluating the impact of financial education in mainstream media. World Bank Policy Research Working Paper 640\%.

Haas, J. D. and T. Brownlie (2001). Iron deficiency and reduced work capacity: A critical review of the research to determine a causal relationship. The Journal of Nutrition 131(2), 676S-690S.

International Institute for Population Sciences (IIPS) and Macro International (2008). National Family Health Survey (NFHS-3), India, 2005-06: Bihar. Mumbai: IIPS.

Jensen, R. and E. Oster (2009, August). The power of TV: Cable television and women's status in India. The Quarterly Journal of Economics 124(3), 1057-1094. 
Kearney, M. and P. Levine (2014). Media influences and social outcomes: The effect of MTV's 16 and Pregnant on teen childbearing. NBER Working Paper.

Kumar, N., S. Rajiv, and A. Jeuland (2001). Effectiveness of trade promotions: Analyzing the determinants of retail pass through. Marketing Science 20(4), 382-404.

La Ferrara, E., A. Chong, and S. Duryea (2012). Soap operas and fertility: Evidence from brazil. American Economic Journal: Applied Economics 4(4), 1-31.

Lozoff, B. (2007). Iron deficiency and child development. Food $\&$ Nutrition Bulletin 28(Supplement 4), 560S-571S.

Lozoff, B., J. Beard, J. Connor, B. Felt, M. Georgieff, and T. Schallert (2006). Long-Lasting Neural and Behavioral Effects of Iron Deficiency in Infancy. Nutrition Reviews 64(s2), S34-S43.

Mudur, G. (2013, June 9). Doubts on fortified midday-meal salt - safe but no clear proof it increases haemoglobin: Scientists. The Telegraph.

Nair, K., G. Brahmam, S. Ranganathan, K. Vijayaraghavan, B. Sivakumar, K. Krishnaswamy, et al. (1998). Impact evaluation of iron \& iodine fortified salt. The Indian Journal of Medical Research 108, 203.

Nair, K. M., B. Sesikeran, S. Ranganathan, and B. Sivakumar (1998). Bioeffect and safety of long-term feeding of common salt fortified with iron and iodine (double fortified salt) in rats. Nutrition Research 18(1), 121-129.

National Institute of Nutrition (India) (2005). Double Fortified Common Salt (DFS) as a Tool to Control Iodine Deficiency Disorders and Iron Deficiency Anaemia: A Report. National Institute of Nutrition.

Paluck, E. L. and D. P. Green (2009). Deference, dissent, and dispute resolution: An experimental intervention using mass media to change norms and behavior in rwanda. American Political Science Review 103(4).

Penninx, B. W., M. Pahor, M. Cesari, A. M. Corsi, R. C. Woodman, S. Bandinelli, J. M. Guralnik, and L. Ferrucci (2004). Anemia is associated with disability and decreased physical performance and muscle strength in the elderly. Journal of the American Geriatrics Society 52(5), 719-724.

Peters, R., L. Burch, J. Warner, N. Beckett, R. Poulter, and C. Bulpitt (2008). Haemoglobin, anaemia, dementia and cognitive decline in the elderly, a systematic review. BMC Geriatrics 8(1), 18.

Planning Commission and others (2013). Press note on poverty estimates, 2011-12. Technical report, Government of India.

Ranganathan, S. and B. Sesikeran (2008). Development of the Double-Fortified Salt from the National Institute of Nutrition. In Symposium on Food Technology for Better Nutrition. Institute of Food Technologists.

Rogers, E. M. and P. W. Vaughan (2000). A staged model of communication effects: Evidence from an entertainment-education radio soap opera in Tanzania. Journal of Health Communication 5, $203-227$. 
Rogers, E. M., P. W. Vaughan, R. Swalehe, N. Rao, P. Svenkerud, and S. Sood (1999). Effects of an entertainmenteducation radio soap opera on family planning behaviour in Tanzania. Studies in Family Planning 30(3), 193-211.

Sivakumar, B., G. N. V. Brahmam, K. M. Nair, S. Ranganathan, M. V. Rao, K. Vijayaraghavan, and K. Krishnaswamy (2001). Prospects of fortification of salt with iron and iodine. British Journal of Nutrition 85, S167-S173.

Solórzano, I., A. Bank, R. Peña, H. Espinoza, M. Ellsberg, and J. Pulerwitz (2008). Catalyzing personal and social change around gender, sexuality, and HIV: Impact evaluation of Puntos de Encuentro's communication strategy in Nicaragua. Unpublished.

Statehealthsocietybihar.org (2015). Ranking.

Stoltzfus, R. J. (2001). Defining iron-deficiency anemia in public health terms: A time for reflection. The Journal of Nutrition 131(2), 565S-567S.

Usdin, S., E. Scheepers, S. Goldstein, and G. Japhet (2005). Achieving social change on gender-based violence: A report on the impact evaluation of soul city's fourth series. Social Science and Medicine 61(11), $2434-45$.

Viteri, F. E. (1998). Prevention of iron deficiency. Prevention of micronutrients deficiencies. Tools for policymakers and public health workers. Washington: National Academy Press, 45-102.

Wendt, A., R. Stephenson, M. Young, A. Webb-Girard, C. Hogue, U. Ramakrishnan, and R. Martorell (2015). Individual and facility-level determinants of iron and folic acid receipt and adequate consumption among pregnant women in rural Bihar, India. PloS ONE 10(3), e0120404. 